\title{
Tail Bifurcation in a Yellow-bellied House Gecko, Hemidactylus flaviviridis Rüppel 1835, in Chitwan, Nepal
}

\author{
Santosh Bhattarai ${ }^{1}$, Babu Ram Lamichhane ${ }^{1}$, and Naresh Subedi ${ }^{2}$ \\ ${ }^{1}$ National Trust for Nature Conservation-Biodiversity Conservation Center, Ratnanagar-06, Chitwan-44204, Nepal (santosh.bhattarai@hotmail.com) \\ ${ }^{2}$ National Trust for Nature Conservation, P.O. Box 3712, Khumaltar, Lalitpur-44700, Nepal
}

$\mathrm{O}$ $\mathrm{f}$ the six species of house geckos (genus Hemidactylus) known to occur in Nepal, the Yellow-bellied House Gecko (Hemidactylus flaviviridis) is the largest and has the most extensive distribution (Schleich and Kästle 2002). Yellow-bellied House Geckos occur sympatrically with other house geckos, functioning largely as human commensals but also exploiting natural habitats such as trees and rocks (Schleich and Kästle 2002; Shah and Tiwari 2004; Bhatttarai et al. 2017, 2018).

Many lizards, including most geckos, are known to shed their tails as an escape mechanism (e.g., Domínguez-López et al. 2015), although tail loss also has been attributed to intraspecific territorial aggression and mating events (e.g., Koleška and Jablonski 2015). When lost or damaged tails are regenerated, abnormalities such as multiple tails sometimes occur (e.g., Arnold 1988; Gogliath et al. 2012; Yankanchi

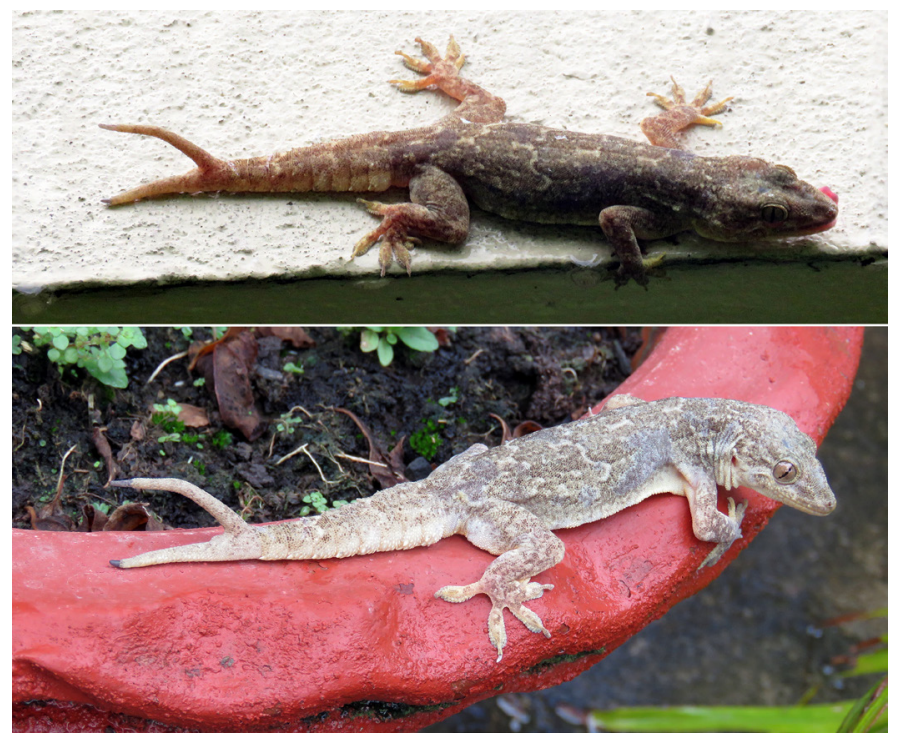

Fig. 1. An adult Yellow-bellied House Gecko (Hemidactylus flaviviridis) with a bifurcated tail. Photographs by Dip Prasad Chaudhary/NTNCBCC (top) and Santosh Bhattarai (bottom). and Kumbar 2016). Herein we report an adult Hemidactylus flaviviridis with a bifurcated tail from Chitwan, to the best of our knowledge the first such case for any lizard in Nepal.

At 2035 h on 28 July 2019, we observed an adult Yellow-bellied House Gecko with a bifurcated tail (Fig. 1) at Ratnanagar-06, Bachhauli, Chitwan, Nepal $\left(27^{\circ} 34^{\prime} 53^{\prime \prime N}\right.$, $\left.84^{\circ} 30^{\prime} 16^{\prime \prime E}\right)$. The individual appeared healthy with no evident injuries or malformation other than the bifid tail. The autotomized portion was almost equal in length to the original. We released the gecko at the site of capture and monitored it for the next ten days, frequently observing it during the day (Fig. 1).

Multiple tails have been recorded for many species of lizards, including $H$. flaviviridis in Maharashtra, India (Kumbar et al. 2011). Although a bifurcated tail could possibly affect locomotion in some instances, some individuals with multiple tails can survive and reproduce despite the abnormality (e.g., Cunha Passos et al. 2014). We suggest that detailed studies could lead to a better understanding of performance by such malformed individuals.

\section{Acknowledgements}

We thank the National Trust for Nature Conservation for logistical support. We also thank Dip Prasad Chaudhary and Surendra Chaudhary from the NTNC-Biodiversity Conservation Center, Sauraha, Chitwan, for assistance in the field.

\section{Literature Cited}

Arnold, E.N.1988. Caudal autotomy as a defense, pp. 235-273. In: C. Gans and R.B. Huey (eds.), Biology of the Reptilia. Volume 16, Ecology B. Defense and Live History. Alan R. Liss, Inc., New York, New York.

Bhattarai, S., C.P. Pokheral, B.R. Lamichhane, and N. Subedi. 2017. Herpetofauna of a Ramsar Site: Beeshazar and associated lakes, Chitwan National Park, Nepal. Reptiles \& Amphibians 24: 17-29.

Bhattarai, S., C.P. Pokheral, B.R. Lamichhane, U.R. Regmi, A.K. Ram, and N. Subedi. 2018. Amphibians and reptiles of Parsa National Park, Nepal. Amphibian \& Reptile Conservation 12: 35-48. 
Cunha Passos, D., L. Tavares Pinheiro, C.A. Barbosa Galdino, and C.F. Duarte Rocha.2014. Tropidurus semitaeniatus (Calango de Lagedo). Tail bifurcation. Herpetological Review 45: 138.

Domínguez-López, M.E., Á.M. Ortega-León, and G. Zamora-Abrego. 2015. Tail autotomy effects on the escape behavior of the lizard Gonatodes albogularis (Squamata: Sphaerodactylidae), from Córdoba, Colombia. Revista Chilena de Historia Natural 88: 1 (DOI 10.1186/s40693-014-0010-6).

Gogliath, M., L.C.M. Pereira, P.A. Nicola, and L.B. Ribeiro. 2012. Ameiva ameiva (Giant Ameiva). Bifurcation. Herpetological Review 43: 129.

Koleška, D. and D. Jablonski. 2015. Tail trifurcation recorded in Algyroides nigro- punctatus (Duméril \& Bibron, 1839). Ecologica Montenegrina 3: 26-28.

Kumbar, S.M., A.B. Ghadage, and V.M. Shendage. 2011. Hemidactylus flaviviridis (House Gecko). Bifurcation. Herpetological Review 42: 94.

Schleich, S.H. and W. Kästle (eds.). 2002. Amphibians and Reptiles of Nepal: Biology, Systematics, Field Guide. A.R.G. Gantner Verlag K.G., Ruggell, Liechtenstein.

Shah, K.B. and S. Tiwari. 2004. Herpetofauna of Nepal: A Conservation Companion. IUCN Nepal, Kathmandu, Nepal.

Yankanchi, S.R. and S.M. Kumbar. 2016. Bifid tail in Hemidactylus prashadi (Smith, 1935). Reptile Rap 18: 34-35. 